\title{
Microstructural Characterization of Beryllium Treated Al-Si Alloys
}

\author{
M. F. Ibrahim, ${ }^{1}$ S. A. Alkahtani, ${ }^{2}$ Kh. A. Abuhasel, ${ }^{2}$ and F. H. Samuel ${ }^{1}$ \\ ${ }^{1}$ Département des Sciences Appliquées, Université du Québec à Chicoutimi, Chicoutimi, QC, Canada G7H 2B1 \\ ${ }^{2}$ Mechanical Engineering Department, College of Engineering, Prince Sattam bin Abdulaziz University, Al Kharj 11942, Saudi Arabia
}

Correspondence should be addressed to F. H. Samuel; fhsamuel@uqac.ca

Received 7 August 2015; Accepted 13 September 2015

Academic Editor: Francesco Delogu

Copyright (C) 2015 M. F. Ibrahim et al. This is an open access article distributed under the Creative Commons Attribution License, which permits unrestricted use, distribution, and reproduction in any medium, provided the original work is properly cited.

\begin{abstract}
The present study was carried out on B356 and B357 alloys using the thermal analysis technique. Metallographic samples prepared from these castings were examined using optical microscopy and FESEM. Results revealed that beryllium causes partial modification of the eutectic Si, similar to that reported for magnesium additions. Addition of $0.8 \mathrm{wt} \% \mathrm{Mg}$ reduces the eutectic temperature by $\sim 10^{\circ} \mathrm{C}$. During solidification of alloys containing high levels of Fe and $\mathrm{Mg}$, but no $\mathrm{Sr}$, formation of a Be-Fe phase was detected at $611^{\circ} \mathrm{C}$, close to that of $\alpha$-Al. The Be-Fe phase precipitates in script-like form at or close to the $\beta$ - $\mathrm{Al}_{5} \mathrm{SiFe}$ platelets. $\mathrm{A}$ new reaction, composed of fine particles of $\mathrm{Si}$ and $\pi$-Fe phase, was observed to occur near the end of solidification in high $\mathrm{Mg}$-, high Fe-, and Be-containing alloys. The amount of this reaction decreased with the addition of Sr. Occasionally, Be-containing phase particles were observed as part of the reaction. Addition of Be has a noticeable effect on decreasing the $\beta$-Al ${ }_{5} \mathrm{FeSi}$ platelet length; this effect may be enhanced by addition of Sr. Beryllium addition also results in precipitation of the $\beta$ - $\mathrm{Al}_{5} \mathrm{FeSi}_{\text {phase in nodular }}$ form, which lowers its harmful effects on the alloy mechanical properties.
\end{abstract}

\section{Introduction}

Bäckerud et al. [1] reported that the main reactions to be observed in the Al-7\% Si- $0.56 \% \mathrm{Mg}$ alloy containing 0.14 wt. $\%$ Fe are (i) the formation of primary $\alpha$-Al dendrites, (ii) the formation of the $\mathrm{Al}$-Si eutectic phase along with the $\beta-\mathrm{Al}_{5} \mathrm{FeSi}$ phase, and (iii) the formation of secondary eutectic phases. It will be observed that there are two possible reactions required for the formation of the $\pi$-phase. The first is a result of the transformation of the $\beta$ - $\mathrm{Al}_{5} \mathrm{FeSi}$ phase into the $\pi$-phase through a peritectic reaction. The general microstructure of Al-7\%Si-Mg alloys consists of (i) primary $\alpha$-Al, (ii) $\mathrm{Mg}_{2} \mathrm{Si}$ displaying Chinese script morphology, (iii) $\beta$-phase $\left(\mathrm{Al}_{5} \mathrm{FeSi}\right)$ with its plate-like morphology, and (iv) the script-like $\pi$ phase $\left(\mathrm{Al}_{8} \mathrm{Mg}_{3} \mathrm{FeSi}_{6}\right)$ [1].

Phragmén [2] reported that the composition of the $\beta$ $\mathrm{Al}_{5} \mathrm{FeSi}$ phase is $27 \mathrm{wt} . \% \mathrm{Fe}$ and $13.5 \mathrm{wt} . \% \mathrm{Si}$ with a density of $3.30-3.35 \mathrm{~g} / \mathrm{cm}^{3}$, appearing in the form of thin platelets or needles in the microstructure. The $\beta-\mathrm{Al}_{5} \mathrm{FeSi}$ phase grows in a lateral or faceted mode and contains multiple (001) growth twins parallel to the growth direction [3]. The first suggestion of the stoichiometry of the $\pi$-phase, from the work of Foss et al. [4], was $\mathrm{Al}_{9} \mathrm{FeMg}_{3} \mathrm{Si}_{5}$, which deviates from the $\mathrm{Al}_{8} \mathrm{Mg}_{3} \mathrm{FeSi}_{6}$ suggested by others $[1,5]$. The $\pi$ phase is a quaternary phase having a script-like morphology, often linked with $\beta-\mathrm{Al}_{5} \mathrm{FeSi}[5]$. The chemical composition of the $\pi$-phase, observed only in two possible morphologies, is 10.9 wt.\% $\mathrm{Fe}, 32.9$ wt.\% Si, and 14.1 wt.\% Mg, with a density of $2.82 \mathrm{~g} / \mathrm{cm}^{3}$ [5-7].

It has been observed that the addition of strontium acts as an obstacle for the nucleation of the $\beta-\mathrm{Al}_{5} \mathrm{FeSi}$ platelets, by reducing the number of sites ultimately available for nucleation. As a result, the $\beta-\mathrm{Al}_{5} \mathrm{FeSi}$ phase precipitates at a smaller number of sites, leading to the precipitation of needles which are larger compared to those in the nonmodified alloy [8]. It has been reported that for a 319 alloy containing 0.46 wt.\% Fe and solidified at a slow cooling rate, the optimum Sr levels lie closer to the limit of $400 \mathrm{ppm}$ : as the Fe level increases, the optimum Sr level will be observed to shift towards the higher limit [9]. 


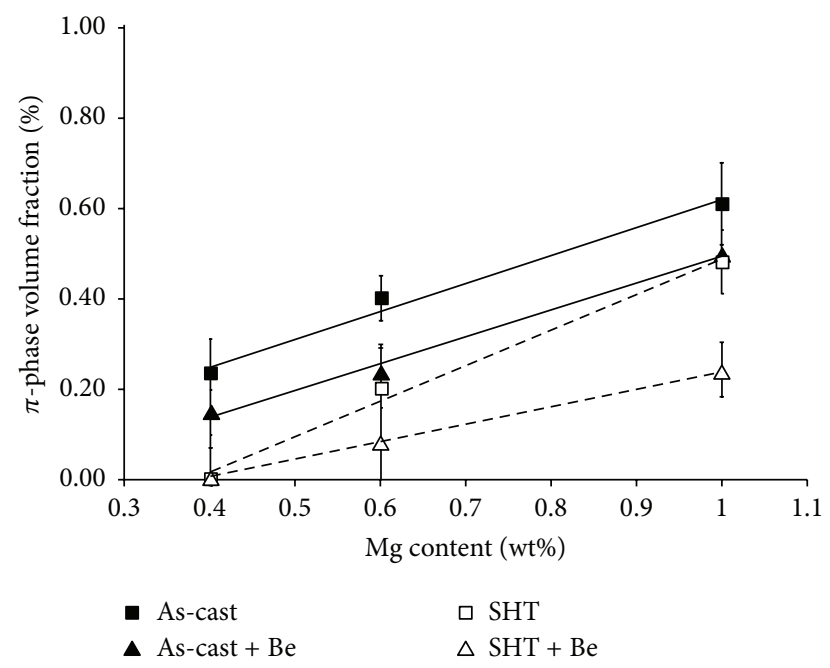

FIGURE 1: An example of the effect of Be addition on the volume fraction of the $\pi$-phase in nonmodified Al-7Si- $x \mathrm{Mg}-0.1 \mathrm{Fe} \mathrm{Be}-$ containing alloys [5].

For Al-Si-Fe-Mg cast alloys, prior investigations have shown that the amount of $\pi$-phase and $\beta$-phase may remain constant regardless of the $\mathrm{Mg}$ content, whereas the amount of $\mathrm{Mg}_{2} \mathrm{Si}$ increases [10]. Cáceres et al. [11] studied the microstructures of two Al-Si-Mg casting alloys, respectively, containing 0.4 wt. $\%$ and 0.7 wt. $\% \mathrm{Mg}$. It was observed that the iron intermetallic phases in high $\mathrm{Mg}$-content alloys are larger than those are in alloys containing low levels of $\mathrm{Mg}$ and that the Fe-rich intermetallic phases in low-Mg alloys were exclusively small $\beta$ - $\mathrm{Al}_{5} \mathrm{FeSi}$ phase plates, while large $\pi$-phase $\left(\mathrm{Al}_{8} \mathrm{Mg}_{3} \mathrm{FeSi}_{6}\right)$ particles were dominant in high-Mg alloys together with a small proportion of the $\beta-\mathrm{Al}_{5} \mathrm{FeSi}$ phase. It has been observed that the addition of $\mathrm{Mg}$ to $\mathrm{Al}-\mathrm{Si}-\mathrm{Mg}$ casting alloys, at three different cooling rates, changes the solidification sequence and the type of iron intermetallic phase formed [1]. At $\mathrm{Mg}$ additions of more than $1.0 \mathrm{wt} . \%$ to molten 319 type alloys, the amount of the $\beta-\mathrm{Al}_{5} \mathrm{FeSi}$ phase is reduced as a result of the transformation of the $\beta$-phase into the $\pi-\mathrm{Al}_{8} \mathrm{Mg}_{3} \mathrm{FeSi}_{6}$ phase [12]. It has been reported that increasing the $\mathrm{Mg}$ content from 0.4 to $0.7 \mathrm{wt} . \%$ in 357 alloys significantly increases the potential for the formation of the Mg-containing $\mathrm{Al}_{8} \mathrm{FeMg}_{3} \mathrm{Si}_{6}$ iron intermetallic phase [13].

The present study is an extension of the work carried by Elsharkawi, Figure 1 [5], on the effects of metallurgical parameters on the decomposition of the $\pi-\mathrm{Al}_{8} \mathrm{Mg}_{3} \mathrm{FeSi}_{6}$ phase in $\mathrm{Al}-\mathrm{Si}-\mathrm{Mg}$ alloys, with an emphasis on the role of $\mathrm{Be}, \mathrm{Sr}$ in the microstructural features of B356 and B357 alloys, by first considering the role of increasing both the $\mathrm{Mg}$ and Fe content.

\section{Experimental Procedure}

Both B356 and B357 alloys were investigated in the present study. The $\mathrm{Mg}$ level was increased by adding pure $\mathrm{Mg}$ to the alloy melts to obtain $\mathrm{Mg}$ levels of $0.4 \mathrm{wt} . \%, 0.6 \mathrm{wt} . \%$, and 0.8 wt. $\%$. The Fe and Be were added in the form of Al- 25 wt. $\%$
TABLE 1: Average chemical composition (wt\%) of the 356 and 357 alloys studied.

\begin{tabular}{lccccccc}
\hline \multirow{2}{*}{ Alloy code } & \multicolumn{7}{c}{ Element concentration (wt\%) } \\
& $\mathrm{Si}$ & $\mathrm{Fe}$ & $\mathrm{Mg}$ & $\mathrm{Ti}$ & $\mathrm{Sr}$ & $\mathrm{Be}$ & $\mathrm{Al}$ \\
\hline $\mathrm{A} 1$ & 7.146 & 0.09 & 0.40 & 0.168 & 0.00 & 0.00 & Bal. \\
A1B & 7.146 & 0.09 & 0.40 & 0.168 & 0.00 & 0.05 & Bal. \\
A1S & 7.146 & 0.09 & 0.40 & 0.168 & 0.02 & 0.00 & Bal. \\
A1BS & 7.146 & 0.09 & 0.40 & 0.168 & 0.02 & 0.05 & Bal. \\
C3 & 7.146 & 0.60 & 0.80 & 0.168 & 0.00 & 0.00 & Bal. \\
C3B & 7.146 & 0.60 & 0.80 & 0.168 & 0.00 & 0.05 & Bal. \\
C3S & 7.146 & 0.60 & 0.80 & 0.168 & 0.02 & 0.00 & Bal. \\
C3BS & 7.146 & 0.60 & 0.80 & 0.168 & 0.02 & 0.05 & Bal. \\
\hline
\end{tabular}

In the above table, codes $\mathrm{A}$ and $\mathrm{C}$ correspond to the Fe levels 0.09 and 0.6, respectively, while codes 1,2 , and 3 correspond to the Mg levels $0.4,0.6$, and 0.8 , respectively. B and S represent Be and Sr, respectively.

Fe and Al-5 wt.\% Be master alloys, respectively, to the alloy melt to obtain Fe levels of 0.09 wt.\%, 0.2 wt.\%, and 0.6 wt.\% and a Be level of 0.05 wt.\%. Sr (0.02 wt.\%) and Ti (0.15 wt.\%) were added to the alloy melts in the form of $\mathrm{Al}-10 \% \mathrm{Sr}$ and Al-5 wt.\% Ti-1 wt.\% B master alloys, for Sr-modification and grain refining purposes, respectively. Table 1 presents the chemical composition of the alloys used in the present study.

Thermal analysis is used to examine the combined interaction between strontium and boron, as well as the likely effect of boron in partial modification of the eutectic Si particles. Near equilibrium conditions (i.e., very slow cooling rate) were achieved through the use of a graphite cup preheated to $600^{\circ} \mathrm{C}$. Approximately 600 grams of the alloy was taken in a $\mathrm{SiC}$ crucible and was poured at $735^{\circ} \mathrm{C} \pm 5^{\circ} \mathrm{C}\left(100^{\circ} \mathrm{C}\right.$ above the liquidus). The temperature was measured by K-type (chromel-alumel) thermocouples located at the centerline position within the sample cup at midheight. Cooling curves were recorded and the castings were sectioned perpendicular to the axis of the cylinder, at the level of the thermocouple, and then polished/etched for metallographic purposes.

The dendrite arm spacing (DAS) values were determined from metallography samples using Climax image analyzer system in conjunction with optical microscope. At least 40 measurements were made for each sample and the average value of at least 100 dendrites was taken to represent the DAS value for the corresponding level.

A quantitative evaluation of the eutectic Si particle characteristics was carried out using image analysis. From these measurements, the average value and standard deviation were obtained in each case. Samples for metallography were examined using optical microscopy as well as scanning electron microscopy (SEM), coupled with energy dispersive $\mathrm{X}$-ray spectrometry (EDS), and wavelength dispersion spectrometry (WDS) detectors.

\section{Results and Discussion}

3.1. Si Particles. The silicon particle characteristics for the various alloy compositions investigated are summarized in Table 2, in which the Si particle measurements for the A1 base alloy samples, with low $\mathrm{Mg}$ and low Fe content using 
TABLE 2: Silicon particle measurements for the as-cast 357 alloy samples (obtained from graphite mold castings, DAS $65 \mu \mathrm{m}$ ).

\begin{tabular}{|c|c|c|c|c|c|c|c|c|}
\hline \multirow{2}{*}{ Alloy (condition) } & \multicolumn{2}{|c|}{ Area $\left(\mu \mathrm{m}^{2}\right)$} & \multicolumn{2}{|c|}{ Length $(\mu \mathrm{m})$} & \multicolumn{2}{|c|}{ Roundness ratio (\%) } & \multicolumn{2}{|c|}{ Aspect ratio } \\
\hline & Av. & $\mathrm{SD}$ & Av. & SD & Av. & $\mathrm{SD}$ & Av. & $\mathrm{SD}$ \\
\hline A1 (nonmod.) & 76.70 & 71.50 & 21.60 & 16.30 & 28.4 & 21.8 & 3.52 & 4.54 \\
\hline C3 (nonmod.) & 20.70 & 22.70 & 9.63 & 7.98 & 36.2 & 21.4 & 2.86 & 5.84 \\
\hline A1B (Be mod.) & 49.60 & 52.40 & 15.20 & 12.00 & 33.8 & 21.8 & 2.85 & 3.45 \\
\hline C3B (Be mod.) & 13.60 & 14.30 & 6.75 & 5.08 & 43.7 & 22.2 & 2.27 & 1.15 \\
\hline A1S (Sr mod.) & 3.18 & 3.21 & 3.05 & 2.16 & 46.0 & 19.2 & 2.11 & 2.14 \\
\hline C3S (Sr mod.) & 4.48 & 4.78 & 3.82 & 3.07 & 43.4 & 21.5 & 2.46 & 3.87 \\
\hline AlBS (Be + Sr mod.) & 2.75 & 2.94 & 3.00 & 2.38 & 43.5 & 19.5 & 2.18 & 2.25 \\
\hline C3BS (Be + Sr mod.) & 3.38 & 3.97 & 3.27 & 2.69 & 43.9 & 19.8 & 2.15 & 1.32 \\
\hline
\end{tabular}

the graphite mold giving a DAS of $\sim 65 \mu \mathrm{m}$, are listed. It can be seen that the Si particle area decreased from 76.70 to $3.18 \mu \mathrm{m}^{2}$, the Si particle length decreased from 21.60 to $3.05 \mu \mathrm{m}$, and the aspect ratio decreased from 3.52 to 2.11 , while the roundness ratio increased from 28.4 to $46.0 \%$ after Sr-modification in the alloy A1S sample. In the case of Be addition (alloy A1B), the Si particle area decreased to $49.60 \mu \mathrm{m}^{2}$, the Si particle length decreased to $15.20 \mu \mathrm{m}$, and the aspect ratio decreased to 2.85 , while the roundness ratio increased to $33.8 \%$. The presence of both $\mathrm{Sr}$ and Be in alloy A1BS resulted in decreasing the Si particle area to $2.75 \mu \mathrm{m}^{2}$, decreasing the Si particle length to $3.0 \mu \mathrm{m}$, decreasing the aspect ratio to 2.18 , and increasing the roundness ratio to 43.5\%. After increasing the Mg and Fe contents (alloy C3), the Si particle area decreased to $20.7 \mu \mathrm{m}^{2}$, the Si particle length decreased to $9.63 \mu \mathrm{m}$, and the aspect ratio decreased to 2.86 , while the roundness ratio increased to $36.2 \%$. The combined effect of the four elements (alloy C3BS) resulted in decreasing the Si particle area to $3.38 \mu \mathrm{m}^{2}$, decreasing the Si particle length to $3.27 \mu \mathrm{m}$, decreasing the aspect ratio to 2.15 , and increasing the roundness ratio to $43.9 \%$. The values listed reflect the modification effect of $\mathrm{Sr}$ and partial modification effects of $\mathrm{Mg}$ and $\mathrm{Be}$, but with increasing Fe levels it appears that most of the Be reacts with the Fe to form a Be-Fe phase (most probably, $\mathrm{Al}_{8} \mathrm{Fe}_{2} \mathrm{BeSi}[14]$ ), thereby reducing the partial modification effect attributed to Be.

\subsection{Thermal Analysis}

3.2.1. Effects of Iron and Magnesium Content. Thermal analysis was carried out to determine the precipitation sequence and formation temperature of the intermetallic phases observed in the 357 alloys containing different levels of Fe and $\mathrm{Mg}$. In this respect, alloys $\mathrm{A} 1, \mathrm{C} 3 \mathrm{BS}$, and $\mathrm{C} 3 \mathrm{~B}$ were selected as examples. The reactions and corresponding temperatures observed in the cooling curves for the alloys studied are summarized in Table 3. Figure 2(a) represents solidification of the base alloy A1, showing the precipitation of $\alpha$-Al (1), followed by formation of the Al-Si eutectic phase (2), together with the precipitation of the $\beta-\mathrm{Al}_{5} \mathrm{FeSi}$. It is expected that as solidification proceeds, the $\beta$-phase content present will be transformed into the $\pi$-phase as a result of the preeutectic reaction (3), $\mathrm{L}+\mathrm{Al}_{5} \mathrm{FeSi} \rightarrow \mathrm{Al}+\mathrm{Si}+\mathrm{Al}_{8} \mathrm{Mg}_{3} \mathrm{FeSi}_{6}$. The last reaction (4) is characterized by a wide peak, which may arise from two merged reactions; first reaction is related to the formation of $\mathrm{Mg}_{2} \mathrm{Si}$ followed by the second reaction which corresponds to the quaternary reaction, $\mathrm{L} \rightarrow \mathrm{Al}+\mathrm{Si}+\mathrm{Mg}_{2} \mathrm{Si}+\mathrm{Al}_{8} \mathrm{Mg}_{3} \mathrm{FeSi}_{6}$.

By comparing the first derivative curve in Figure 2(a) with the one shown in Figure 3(a) for alloys A1 (base alloy) and C3BS, respectively, it will be seen that, at 0.09 wt.\% Fe, for the A1 base alloy, the first derivative curve reveals four peaks, while at 0.6 wt.\% Fe, C3BS alloy, a new peak marked (2) may be observed before the eutectic reaction. This peak corresponds to the formation of the preeutectic $\beta$-phase, while the precipitation of $\mathrm{Mg}_{2} \mathrm{Si}$ was formed with reaction (4). Reaction (5) may be explained as

$$
\mathrm{L}+\mathrm{Al}_{5} \mathrm{FeSi} \longrightarrow \mathrm{Al}+\mathrm{Si}+\mathrm{Al}_{8} \mathrm{Mg}_{3} \mathrm{FeSi}_{6}
$$

where $\beta$ - $\mathrm{Al}_{5} \mathrm{FeSi}$ phase was transformed into the $\pi$-phase. Other reactions remain the same as those described in Figure 4(a).

To reach a better understanding of the effect of Fe content on intermetallic formation, it has been reported $[15,16]$ that increasing the Fe content from 0.09 wt.\% to 0.6 wt.\% changes the solidification sequences of Al-7Si-0.4Mg alloys (base alloy A1), which can be explained by the current thermal analysis. At 0.09 wt. $\% \mathrm{Fe}$, the $\beta$-phase precipitates at low temperatures together with the Al-Si eutectic phase and is characterized by fine platelets in the microstructure, as shown in Figure 2(b). At 0.6 wt. $\%$ Fe, most of the $\beta$-phase will precipitate at high temperatures before the Al-Si eutectic phase. This $\beta$-phase is characterized by much larger size in the microstructure, as shown in Figures 3(b) and 3(c). As a result, increasing the Fe content will increase the size of the $\beta$-phase in the microstructure, which would have a negative effect on the alloy mechanical properties.

For a clear understanding of the effects of $\mathrm{Mg}$ addition on the precipitation sequence and reaction temperature, the $\mathrm{Mg}$ content in Sr-modified alloy C3BS (Figure 5), also in nonmodified alloy C3B (Figure 4), was increased up to $0.8 \mathrm{wt} . \%$. Two separate peaks were identified corresponding to reactions (4) and (5). The reactions and their corresponding formation temperatures during solidification of alloys C3BS and $\mathrm{Al}$, containing high and low $\mathrm{Mg}$ levels, respectively, are listed in Table 3. There is a significant reduction in the eutectic temperature by $\sim 10^{\circ} \mathrm{C}$ in high $\mathrm{Mg}$-containing alloy (C3BS), 
TABLE 3: Main reactions observed from thermal analysis data of alloys A1, C3BS, and C3B.

\begin{tabular}{|c|c|c|}
\hline Alloy code & Temp. $\left({ }^{\circ} \mathrm{C}\right)$ & Reaction [21] \\
\hline \multirow{4}{*}{$\begin{array}{l}\mathrm{A} 1 \\
0.09 \% \mathrm{Fe}-0.4 \% \mathrm{Mg}\end{array}$} & $612(1)$ & Formation of Al-dendritic network \\
\hline & $569(2)$ & $\begin{array}{l}\text { (i) Precipitation of Al-Si-eutectic phase } \\
\text { (ii) Precipitation of posteutectic } \beta-\mathrm{Al}_{5} \mathrm{FeSi} \text { phase }\end{array}$ \\
\hline & $561(3)$ & Transformation of $\beta$-phase into $\pi$ - $\mathrm{Al}_{8} \mathrm{Mg}_{3} \mathrm{FeSi}_{6}$ phase \\
\hline & $546(4)$ & $\begin{array}{l}\text { (i) Precipitation of } \mathrm{Mg}_{2} \mathrm{Si} \\
\text { (ii) Quaternary eutectic reaction* }\end{array}$ \\
\hline \multirow{5}{*}{$\begin{array}{l}\text { C3BS } \\
0.6 \% \mathrm{Fe}-0.8 \% \mathrm{Mg}-0.05 \% \mathrm{Be}- \\
0.02 \% \mathrm{Sr}\end{array}$} & $609(1)$ & Formation of Al-dendritic network \\
\hline & $568(2)$ & Formation of preeutectic $\beta-\mathrm{Al}_{5} \mathrm{FeSi}$ phase \\
\hline & $561(3)$ & $\begin{array}{l}\text { (i) Precipitation of Al-Si-eutectic phase } \\
\text { (ii) Precipitation of posteutectic } \beta-\mathrm{Al}_{5} \mathrm{FeSi} \text { phase }\end{array}$ \\
\hline & $550(4)$ & $\begin{array}{l}\text { (i) Transformation of } \beta \text {-phase into } \pi-\mathrm{Al}_{8} \mathrm{Mg}_{3} \mathrm{FeSi}_{6} \text { phase } \\
\text { (ii) Precipitation of } \mathrm{Mg}_{2} \mathrm{Si}\end{array}$ \\
\hline & $540(5)$ & Quaternary reaction* \\
\hline \multirow{5}{*}{$\begin{array}{l}\mathrm{C} 3 \mathrm{~B} \\
0.6 \% \mathrm{Fe}-0.8 \% \mathrm{Mg}-0.05 \% \mathrm{Be}\end{array}$} & $613(1)$ & Formation of Al-dendritic network \\
\hline & $611(2)$ & Formation of Be-Fe phase \\
\hline & $560(3)$ & $\begin{array}{l}\text { (i) Precipitation of Al-Si-eutectic phase } \\
\text { (ii) Precipitation of posteutectic } \beta-\mathrm{Al}_{5} \mathrm{FeSi} \text { phase }\end{array}$ \\
\hline & $551(4)$ & $\begin{array}{l}\text { (i) Transformation of } \beta \text {-phase into } \pi-\mathrm{Al}_{8} \mathrm{Mg}_{3} \mathrm{FeSi}_{6} \text { phase } \\
\text { (ii) Precipitation of } \mathrm{Mg}_{2} \mathrm{Si}\end{array}$ \\
\hline & $539(5)$ & Quaternary reaction* \\
\hline
\end{tabular}

${ }^{*}$ Quaternary reaction, $\mathrm{L} \rightarrow \mathrm{Al}+\mathrm{Si}+\mathrm{Mg}_{2} \mathrm{Si}+\mathrm{Al}_{8} \mathrm{Mg}_{3} \mathrm{FeSi}_{6}$.

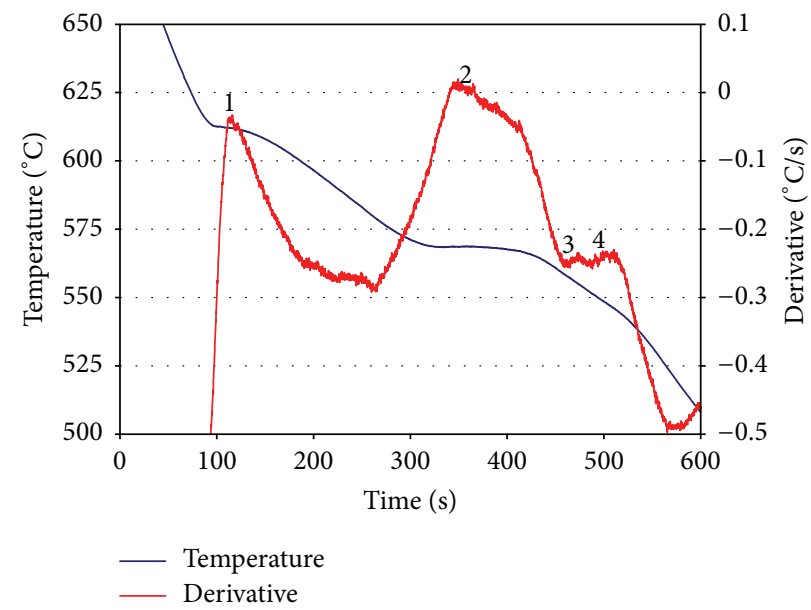

(a)

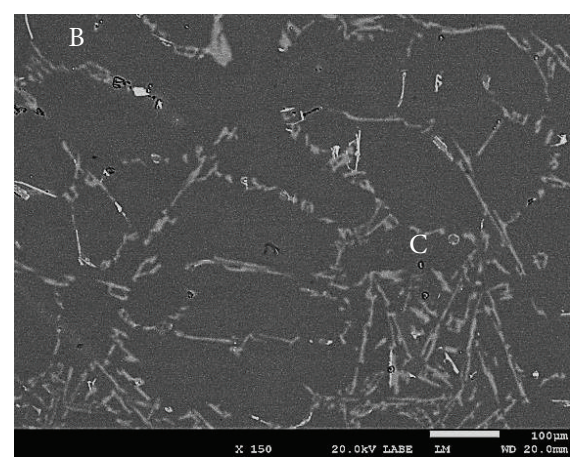

(b)

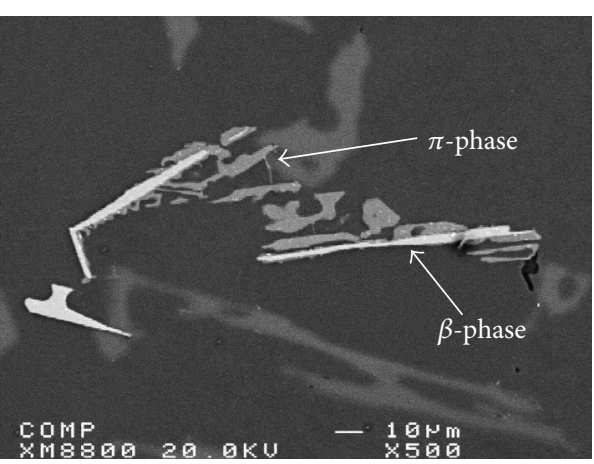

(c)

Figure 2: (a) Temperature-time cooling curve and its first derivative obtained from the base alloy A1, (b) the corresponding microstructure showing small size of the $\beta-\mathrm{Al}_{5} \mathrm{FeSi}$ phase and the $\pi-\mathrm{Al}_{8} \mathrm{Mg}_{3} \mathrm{FeSi}_{6}$ phase particles, and (c) partial transformation of $\beta$ - $\mathrm{Al}_{5} \mathrm{FeSi}$ to $\pi$-phase. 

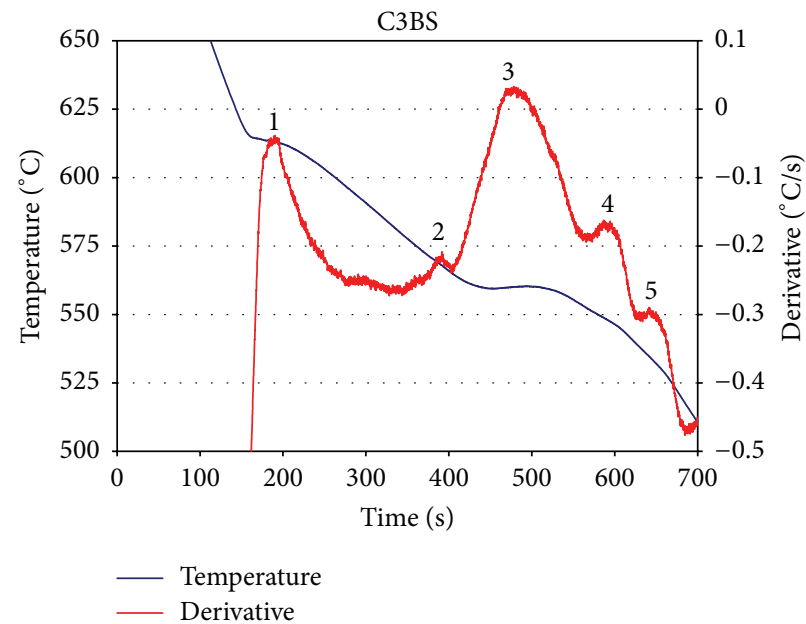

(a)

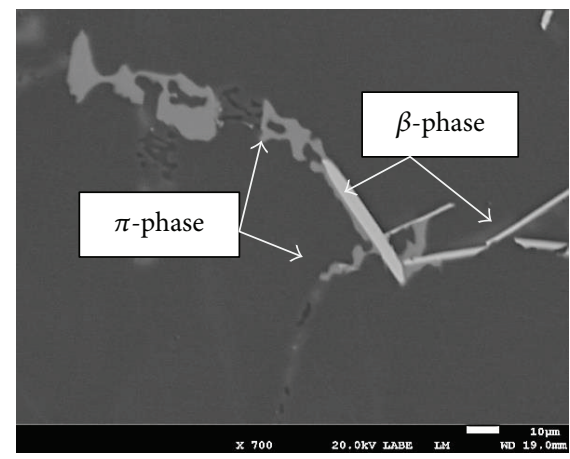

(b)

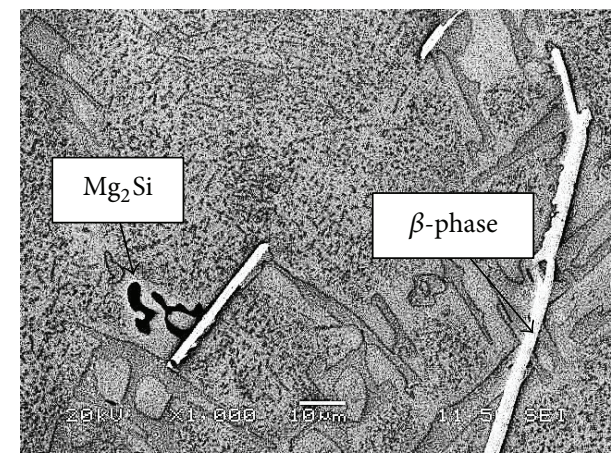

(c)

Figure 3: (a) Temperature-time cooling curve and its first derivative obtained from the alloy C3BS, (b) the corresponding microstructure showing much bigger size of the $\beta$ - $\mathrm{Al}_{5} \mathrm{FeSi}$ phase and the $\pi$-phase particles, and (c) the corresponding microstructure showing much larger size of the $\beta$-phase and the $\mathrm{Mg}_{2}$ Si particles.

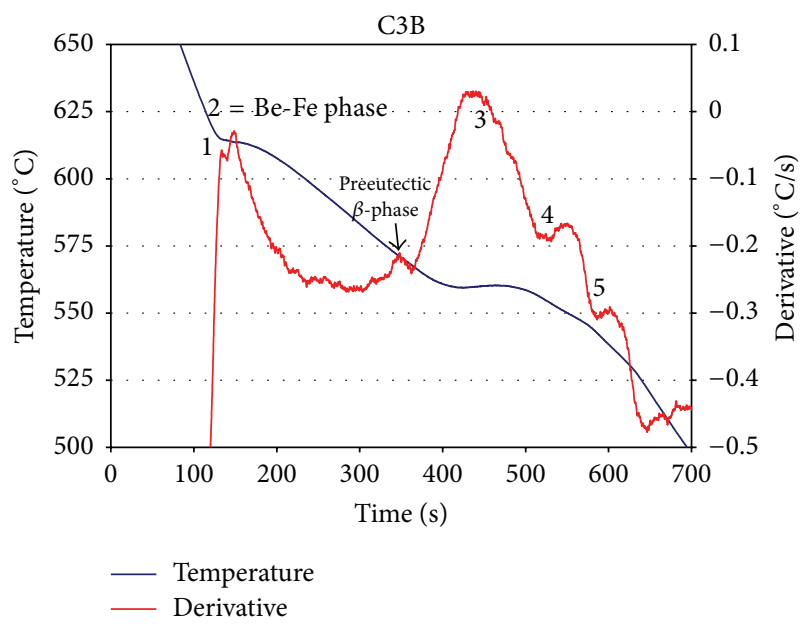

(a)
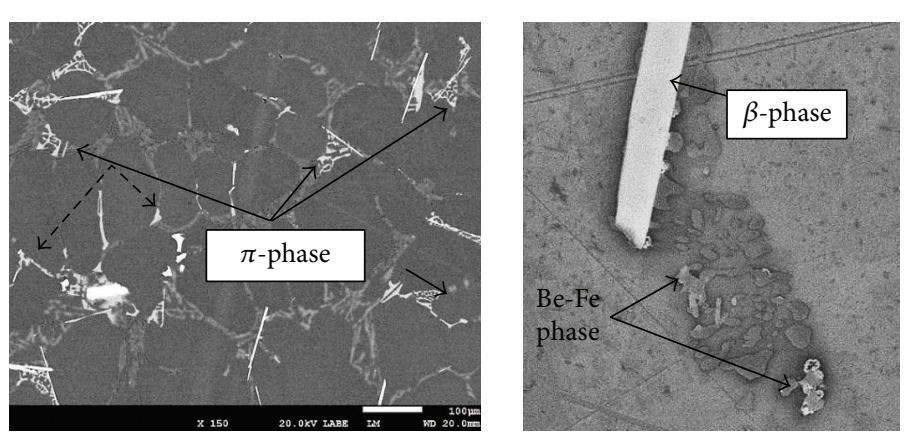

(b) (c)

Figure 4: (a) Temperature-time cooling curve and its first derivative obtained from the nonmodified alloy C3B, (b) the corresponding microstructure showing a noticeable larger size of the nodular $\beta-\mathrm{Al}_{5} \mathrm{FeSi}$ phase (broken arrows) and the $\pi-\mathrm{Al}_{8} \mathrm{Mg}_{3} \mathrm{FeSi}_{6}$ phase particles, and (c) enlarged microstructure showing small particles possibly Be-Fe phase and/or $\pi$-phase particles close to $\beta$-phase plate-black arrows. 

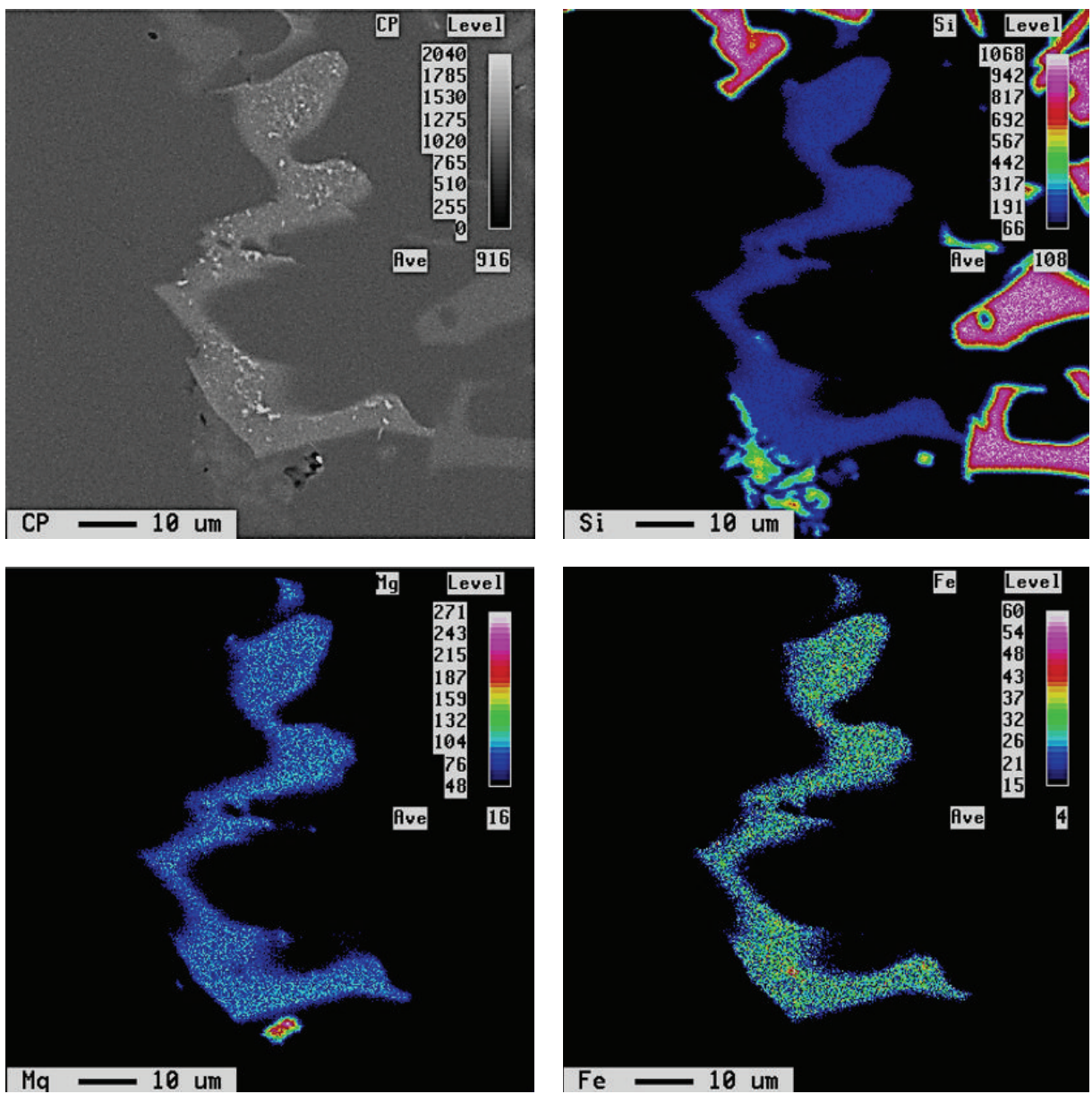

FIGURE 5: Element distribution in $\pi$-phase.

compared to the low $\mathrm{Mg}$-containing alloy (A1), which is in a good agreement with published findings [17]. Moustafa et al. [18] reported that the observed reduction in eutectic temperature affects the modification of the eutectic Si particles.

After an extensive investigation of the microstructure, the $\pi-\mathrm{Al}_{8} \mathrm{Mg}_{3} \mathrm{FeSi}_{6}$ phase is often observed to be in close contact with $\beta-\mathrm{Al}_{5} \mathrm{FeSi}$ phase platelets. Figure $2(\mathrm{c})$ is an enlarged micrograph revealing the transformation of the $\beta$-phase to $\pi$-phase. Thus it may be reasonable to assume that the $\beta$ $\mathrm{Al}_{5} \mathrm{FeSi}$ phase will precipitate first followed by the growth of the $\pi-\mathrm{Al}_{8} \mathrm{Mg}_{3} \mathrm{FeSi}_{6}$ phase from the surface of the $\beta-\mathrm{Al}_{5} \mathrm{FeSi}$ thereafter, according to

$$
\mathrm{L}+\mathrm{Al}_{5} \mathrm{FeSi} \longrightarrow \mathrm{Al}+\mathrm{Si}+\mathrm{Al}_{8} \mathrm{Mg}_{3} \mathrm{FeSi}_{6}
$$

Figure 7 shows the elements distribution in the $\pi$-phase.

3.2.2. Effects of Beryllium Content. The morphology of iron intermetallic shows the precipitation of several types in Becontaining and Be-free alloys. The Fe intermetallics observed in the optical microstructure of the Al-7Si-0.8Mg-0.6Fe$0.05 \mathrm{Be}, \mathrm{C} 3 \mathrm{~B}$ alloy, are (i) the nodular $\mathrm{Fe}-\mathrm{Si}-\mathrm{Al} \beta$-phase and (ii) $\mathrm{Be}-\mathrm{Fe}$ phase $\left(\mathrm{Al}_{8} \mathrm{Fe}_{2} \mathrm{BeSi}\right)$ with a script-like morphology, as presented in Figures 3(b) and 3(c). This observation is in agreement with the reported microstructure of Be-containing
B357 alloys $[19,20]$. It is shown in Figures 5 and 6 that the Be-Fe phase exists near or at the $\beta$-phase platelets. A similar observation can be made from the thermal analysis results of the C3BS alloy. It is estimated that the formation temperature of this reaction is approximately $611^{\circ} \mathrm{C}$ which is close to the formation temperature of $\alpha$-AL; this would facilitate the precipitation of the $\mathrm{Be}-\mathrm{Fe}$ phase in the interdendritic region, within the $\alpha-\mathrm{AL}$, or both, especially in high $\mathrm{Be}$ containing alloys of the order of $0.2 \mathrm{wt} \%$ [14, 20-23]. Also, this temperature is higher than the formation temperature of the preeutectic $\beta-\mathrm{Al}_{5} \mathrm{FeSi}$ phase marked as peak (2) in Table 3 for the Be-free A1 alloy and for the Sr-modified Be-containing C3BS alloy, as shown in Figures 2 and 4.

Based on the thermal analysis data and the corresponding microstructure, the addition of Be resulted in a change in the precipitation sequence of the iron intermetallics where peak (2) (Figure 6(a)) corresponds to the possible formation of the Be-Fe phase. This observation was supported by Murali et al. [20-22], who carried out an interrupted quenching experiment to detect the formation temperature of the $\mathrm{Be}$ $\mathrm{Fe}$ phase $\left(\mathrm{Al}_{8} \mathrm{Fe}_{2} \mathrm{BeSi}\right)$. The authors found that the $\mathrm{Be}-\mathrm{Fe}$ phase exists in the microstructure at the point where the melt quenched from the liquid temperature at $607^{\circ} \mathrm{C}$. However, in the present work, the exact composition of the Be-Fe 


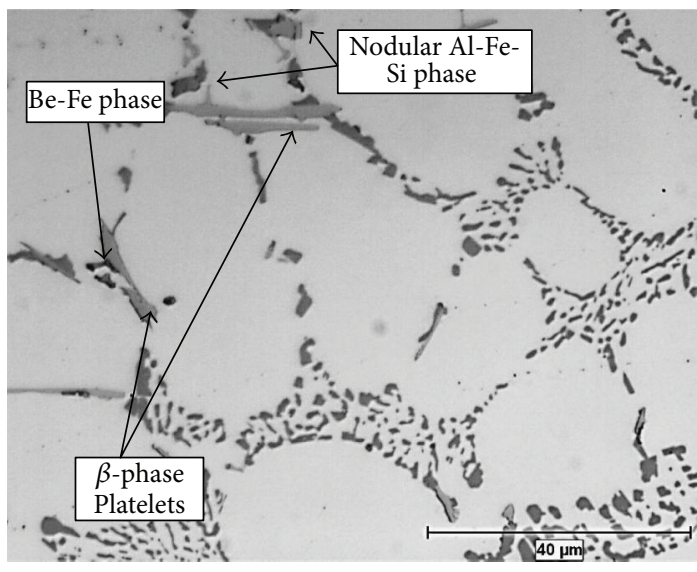

(a)

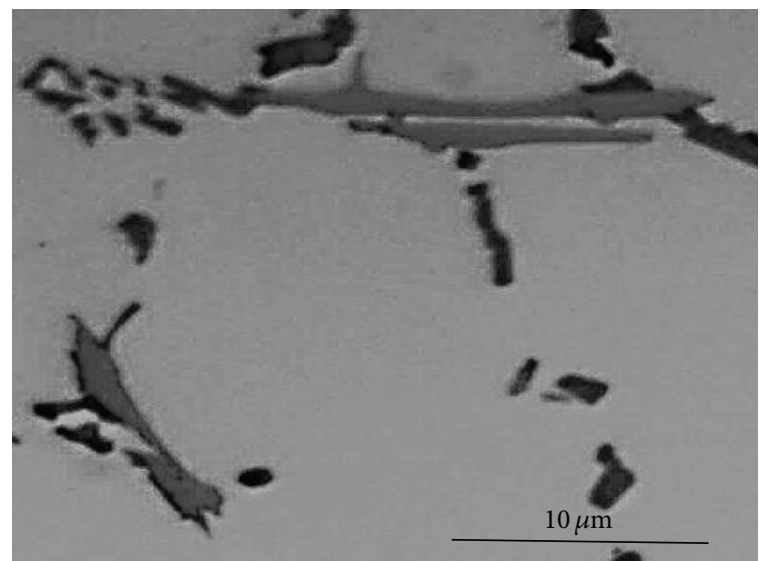

(b)

Figure 6: Optical microstructures of Sr-modified C3BS alloy showing (a) nodular and platelet forms of $\mathrm{Al}_{5} \mathrm{FeSi}, \beta$-phase, and $\pi$-phase particles and possibly Be-Fe containing phase particles. (b) Enlarged portion of (a) revealing the irregular shape of the $\beta$ - $\mathrm{Al}_{5} \mathrm{FeSi}$ platelets.

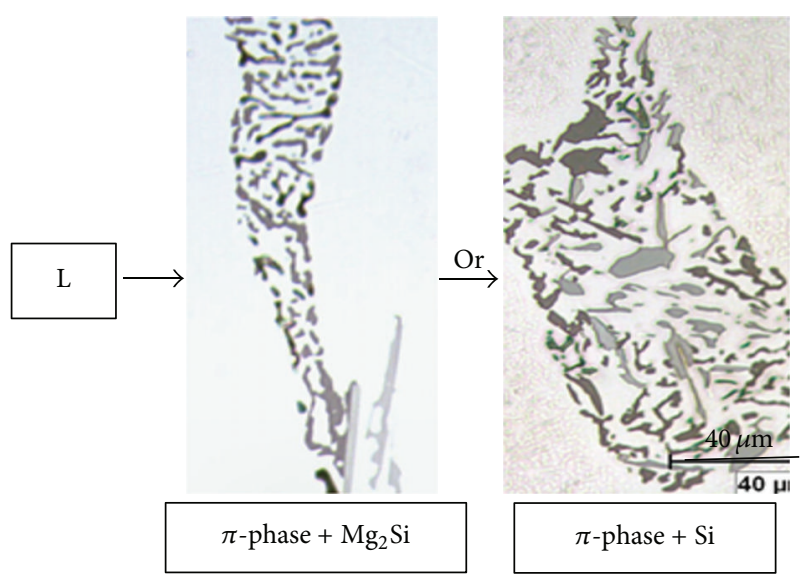

Figure 7: Optical microstructures of Be-containing C3B alloy showing the new eutectic-like reaction sequence.

phase could not be identified with certainty. The precipitation sequence and the corresponding temperatures for the Al-7Si$0.8 \mathrm{Mg}-0.6 \mathrm{Fe}$ Be-containing alloy, in both the nonmodified and Sr-modified conditions $\mathrm{C} 3 \mathrm{~B}$ and C3BS, are listed in Table 3. Figure 8(a) is an optical microstructure of the Srmodified C3BS Be-containing alloy showing nodular Al-Fe$\mathrm{Si}$, in addition to other phases, whereas Figure 6(b) reveals the irregular shape of the $\beta$-phase platelets that may be caused by the addition of $\mathrm{Be}$ and its reaction with $\mathrm{Fe}$.

3.3. Observation of a New Reaction. Figure 3 displays the cooling curve and its first derivative obtained from the C3BS alloy. From an examination of the microstructure of both the nonmodified and Sr-modified, Be-containing alloys, particularly alloys containing higher levels of $\mathrm{Mg}$ and $\mathrm{Fe}$ (alloys $\mathrm{C} 3 \mathrm{~B}$ and C3BS), a new reaction was observed to take place towards the end of solidification at a low cooling rate $\left(0.4^{\circ} \mathrm{C} / \mathrm{s}\right)$, as shown in Figure 7. This new reaction is composed of a mixture of $\mathrm{Mg}_{2} \mathrm{Si}, \pi-\mathrm{Al}_{8} \mathrm{Mg}_{3} \mathrm{FeSi}_{6}$ phase, $\mathrm{Si}$ particles, and
TABLE 4: Solidification times of the A and C3 series of alloys obtained from their cooling curves. Each value is an average of five consecutive tests.

\begin{tabular}{lc}
\hline Alloy code & Solidification time (s) \\
\hline A1 & 452 \\
A1B & 464 \\
A1S & 472 \\
A1BS & 474 \\
C3 & 463 \\
C3B & 492 \\
C3S & 510 \\
C3BS & 504 \\
\hline
\end{tabular}

possibly Be-Fe phase. It should be mentioned here that this reaction was not detected in any of the cooling curves, since the heat associated with this reaction is apparently too low. Table 4 lists the solidification times obtained from the C3 series of alloys. As can be seen, the solidification time for the C3B alloy is $\sim 22$ seconds more than that obtained from the C3 base alloy. It may be suggested that this increase in the solidification time, due to the presence of $\mathrm{Be}$, would result in the decomposition of the remaining liquid metal into the newly observed reaction [24]. However, the exact mechanism by which this reaction took place requires more investigation.

Beryllium and strontium are the main parameters controlling the amount of this new reaction or precipitates. Table 5 summarizes the area and intensity measurements of the new reaction. It is found that addition of Sr to the nonmodified, Be-containing C3B alloy decreased the reaction particle area by $44 \%$ and intensity by $36 \%$, respectively. Figure 8 is an example of the element distribution within the new reaction.

The intermetallic phases present in the alloys studied were of two types: either completely soluble or partially soluble. The $\mathrm{Mg}_{2}$ Si phase was the completely soluble one as observed in the cast structure. This phase appears darker than, or closer 


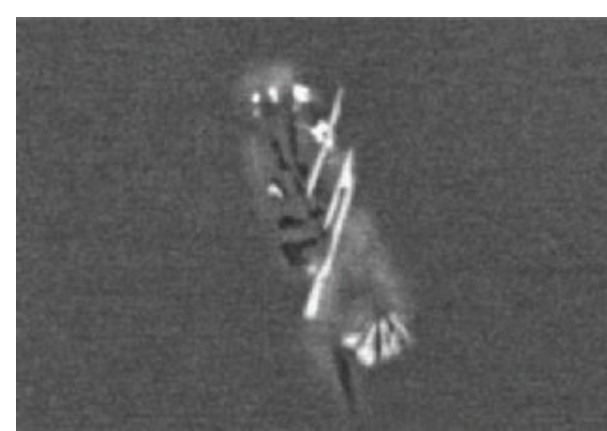

Electron image 1

(a)

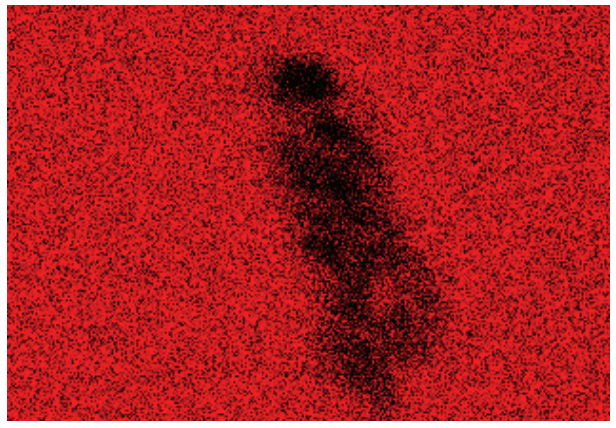

Al Ka1

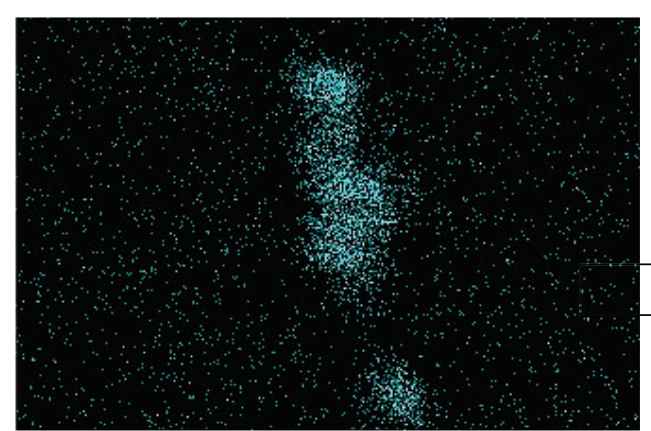

Mg Ka1_2

(b)

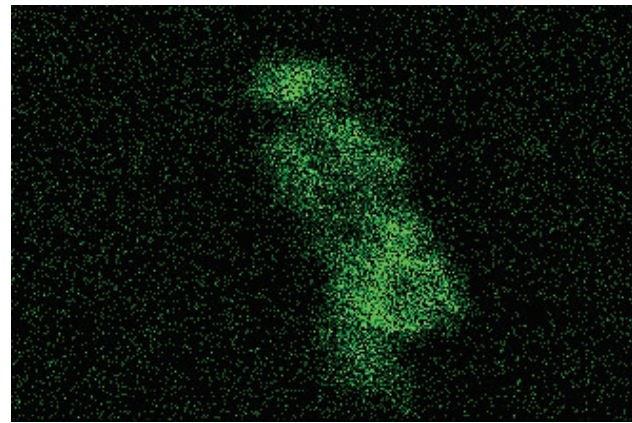

Si Ka1

(c)

(d)

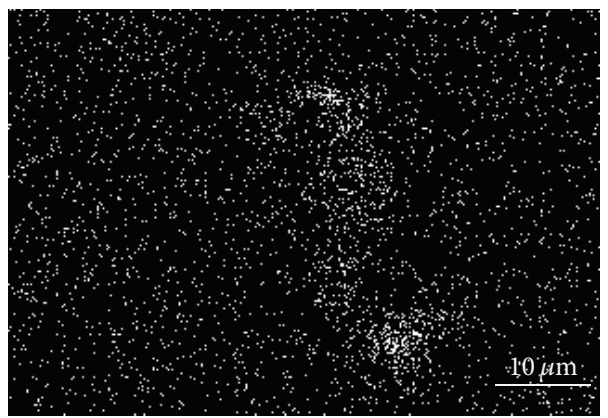

Fe Ka1

(e)

Figure 8: (a) Backscattered image, and images of (b) $\mathrm{Mg}$, (c) $\mathrm{Al}$, (d) $\mathrm{Si}$, and (e) Fe distribution within the new eutectic reaction.

TABLE 5: New reaction particle measurements for the as-cast 357 alloys.

\begin{tabular}{lccccc}
\hline \multirow{2}{*}{ Alloy code } & \multicolumn{2}{c}{ Area $(\%)$} & \multicolumn{2}{c}{ Area $\left(\mu \mathrm{m}^{2}\right)$} & Intensity \\
& Av. & SD & Av. & SD & (particle/field) \\
\hline C3B & 5.87 & 2.46 & 1155.2 & 1242.0 & 17.34 \\
C3BS & 3.30 & 1.64 & 662.8 & 805.5 & 11.22 \\
\hline
\end{tabular}

to, the degree of darkness in the backscattered images of the Al-matrix because of their smaller average atomic number. The $\mathrm{Mg}_{2} \mathrm{Si}$ phase dissolves during the solutionizing treatment where $\mathrm{Mg}$ diffuses into the metal matrix and forms a supersaturated solid solution after quenching. The principal partially soluble phases in the $\mathrm{B} 357$ casting alloys are the $\beta-\mathrm{Al}_{5} \mathrm{FeSi}$ and $\pi-\mathrm{Al}_{8} \mathrm{Mg}_{3} \mathrm{FeSi}_{6}$ compounds, as well as the Be-Fe phase.
An intensive study [5] was carried out on the decomposition of the $\pi-\mathrm{Al}_{8} \mathrm{Mg}_{3} \mathrm{FeSi}_{6}$ phase in an Al-Si-Mg B357-type alloy. This study has addressed this subject in detail, in which the reason leads to concentrating on investigating the characteristics of $\beta-\mathrm{Al}_{5} \mathrm{FeSi}$ phase as the most iron intermetallic phase has a negative effect on the mechanical properties of such casting alloys, where this study has concluded that, after the recommended solution treatment, the Chinese-script $\pi-\mathrm{Al}_{8} \mathrm{Mg}_{3} \mathrm{FeSi}_{6}$ phase is completely decomposed into fine needles of the $\beta-\mathrm{Al}_{5} \mathrm{FeSi}$ phase at $0.4 \mathrm{wt} . \% \mathrm{Mg}$ but appears to only be partially decomposed at higher $\mathrm{Mg}$ contents, namely, $0.6-0.8 \mathrm{wt} . \%$. The second conclusion reported was that adding of $500 \mathrm{ppm}$ of Be reduces the amount of the $\pi$-phase formed in Al7SixMg-0.1Fe alloys; such Be additions also facilitate the decomposition of the $\pi$-phase into the $\beta-\mathrm{Al}_{5} \mathrm{FeSi}$ phase, particularly at higher levels of $\mathrm{Mg}$ content. 


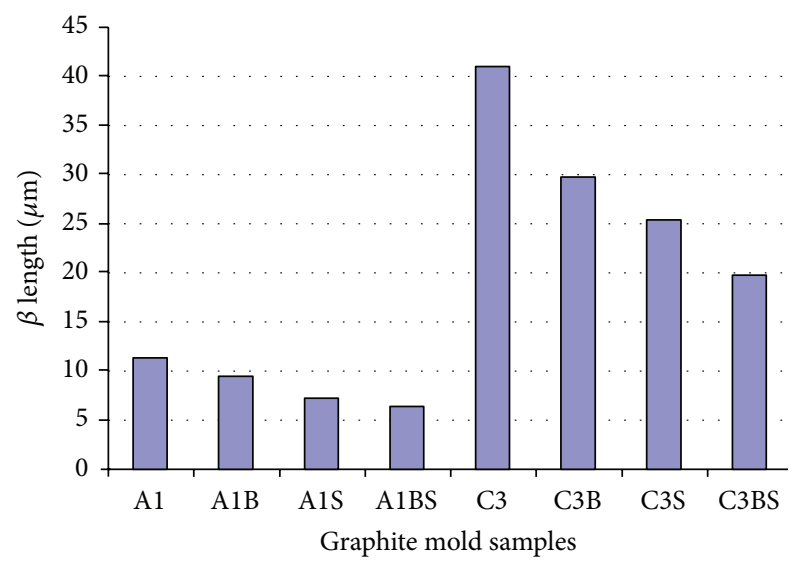

FIGURE 9: Histogram exhibiting the variation in $\beta-\mathrm{Al}_{5} \mathrm{FeSi}$ phase average length affected by the composition of the alloys.

Another conclusion suggested that long solutionizing times lead to a significant reduction in the amount of the $\pi$-phase through the dissolution and decomposition of the $\pi$-phase into fine $\beta-\mathrm{Al}_{5} \mathrm{FeSi}$ phase platelets.

The histogram in Figure 9 illustrates the effects of $\mathrm{Fe}, \mathrm{Mg}$, $\mathrm{Be}$, and $\mathrm{Sr}$ additions on the length of the $\beta-\mathrm{Al}_{5} \mathrm{FeSi}$ phase. It is reported that iron intermetallics are affected by the cooling rate. Thus increasing cooling rate from using a graphite mold (DAS $\sim 5 \mu \mathrm{m}$ ) to a metallic mold (DAS $24 \mu \mathrm{m}$ ) would lead to decreasing the length of the $\beta-\mathrm{Al}_{5} \mathrm{FeSi}$ phase by $\sim 50 \%$. Also, a similar reduction in the $\beta$-phase length can be obtained by adding $\mathrm{Be}$ and/or Sr. Increasing $\mathrm{Mg}$ and $\mathrm{Fe}$ up to 0.6 and 0.8 wt. $\%$, respectively, results in a similar effect of reducing the $\beta$-phase length. Additionally, increasing both of these elements increases the amount of the $\pi$-phase in the matrix. These results agree with the work of Elsharkawi [5].

Figure 9 also illustrates how the addition of 0.02 wt.\% Sr to Al-7Si-Mg-Fe alloys results in a slight decrease in the $\beta$ phase length, or the amount of the $\beta$-phase, when compared to nonmodified alloys. This may be explained in terms of the presence of Sr which results in the breaking up of the $\beta$-phase platelets, as reported by Samuel et al. [25], thereby reducing the length and increasing the density of this $\beta-\mathrm{Al}_{5} \mathrm{FeSi}$ phase platelets. The authors claim that $\mathrm{Sr}$ was absorbed by the $\beta-\mathrm{Al}_{5} \mathrm{FeSi}$ phase platelets leading to their destabilization and fragmentation. This observation may contribute to an increase in the number of $\beta-\mathrm{Al}_{5} \mathrm{FeSi}$ platelets available for the preeutectic reaction to occur, thereby forming further amounts of the $\pi-\mathrm{Al}_{8} \mathrm{Mg}_{3} \mathrm{FeSi}_{6}$ phase.

\section{Conclusions}

Based on the microstructural results obtained from applying thermal analysis, the following conclusions may be drawn:

(1) Beryllium brought about partial modification of eutectic Si particles, for example, $76.7 \mu \mathrm{m}^{2}$ versus $49.60 \mu \mathrm{m}^{2}$, respectively.

(2) Addition of $0.8 \mathrm{wt} . \% \mathrm{Mg}$ reduced the eutectic temperature by $\sim 10^{\circ} \mathrm{C}$.
(3) During solidification of alloys containing high levels of $\mathrm{Fe}$ and $\mathrm{Mg}$ (but no $\mathrm{Sr}$ ), a peak corresponding to the formation of the Be-Fe phase (most probably $\mathrm{Al}_{8} \mathrm{Fe}_{2} \mathrm{BeSi}$ ) was observed; however the exact composition could not be identified with certainty.

(4) The Be-Fe phase precipitates in the form of a scriptlike morphology at or close to $\beta$-platelets.

(5) A new reaction was observed to take place near the end of solidification of high $\mathrm{Mg}$-, high $\mathrm{Fe}-$, and $\mathrm{Be}-$ containing alloys. This new reaction is composed mainly of fine particles of $\mathrm{Si}$ and $\pi-\mathrm{Al}_{8} \mathrm{Mg}_{3} \mathrm{FeSi}_{6}$ phases.

(6) Addition of Be has a noticeable effect on decreasing the $\beta-\mathrm{Al}_{5} \mathrm{FeSi}$ phase length. This effect may be enhanced by the addition of Sr.

\section{Conflict of Interests}

The authors declare that there is no conflict of interests regarding the publication of this paper.

\section{Acknowledgments}

Financial and in-kind support received from the Natural Sciences and Engineering Research Council of Canada is appreciated. The authors would to thank Ms. Amal Samuel for enhancing the quality of the artwork presented in this paper.

\section{References}

[1] S. L. Bäckerud, G. Chai, and J. Tamminen, Solidification Characteristics of Aluminum Alloys Vol 2: Foundry Alloys, AFS/Skanaluminium, Oslo, Norway, 1990.

[2] G. Phragmén, "On the phases occurring in alloys of aluminum with copper, magnesium, manganese, iron, and silicon," Journal of the Institute of Metals, vol. 77, pp. 498-553, 1950.

[3] S. K. Tang and T. Sritharan, "Morphology of $\beta$-AlFeSi intermetallic in Al-7Si alloy castings," Materials Science and Technology, vol. 14, no. 8, pp. 738-742, 1998.

[4] S. Foss, A. Olsen, C. J. Simensen, and J. Taftø, "Determination of the crystal structure of the $\pi$-AlFeMgSi phase using symmetry- and site-sensitive electron microscope techniques," Acta Crystallographica-Section B: Structural Science, vol. 59, no. 1, pp. 36-42, 2003.

[5] E. A. Elsharkawi, Effect of metallurgical parameters on the decomposition of the $\pi$-AlFeMgSi phase in Al-Si-Mg alloys and its influence on the mechanical properties [Ph.D. thesis], Université du Québec à Chicoutimi, Chicoutimi, Canada, 2011.

[6] L. F. Mondolfo, Aluminum Alloys: Structure and Properties, Butterworths, London, UK, 1976.

[7] J. A. Taylor, "The effect of iron in the Al-Si casting alloys," in Proceedings of the 35th Australian Foundry Institute National Conference on Casting Concepts, Adelaide, Australia, October 2004.

[8] A. M. Samuel, F. H. Samuel, and H. W. Doty, "Observations on the formation of $\beta-\mathrm{Al}_{5} \mathrm{FeSi}$ phase in 319 type Al-Si alloys," Journal of Materials Science, vol. 31, no. 20, pp. 5529-5539, 1996.

[9] A. Pennors, A. M. Samuel, F. H. Samuel, and H. W. Doty, "Precipitation of $\beta-\mathrm{Al}_{5} \mathrm{FeSi}$ iron intermetallic in $\mathrm{Al}-6 \mathrm{Si}-3.5 \mathrm{Cu}$ 
(319) type alloys: role of Sr and P,' AFS Transactions, vol. 106, pp. 251-264, 1998.

[10] J. A. Taylor, D. H. StJohn, L. H. Zheng, G. A. Edwards, J. Barresi, and M. J. Couper, "Solution treatment effects in AlSi-Mg casting alloys: part 1-intermetallic phases," Aluminium Transactions, vol. 45, pp. 95-110, 2001.

[11] C. H. Caceres, C. J. Davidson, J. R. Griffiths, and Q. G. Wang, "The effect of $\mathrm{Mg}$ on the microstructure and mechanical behavior of Al-Si-Mg casting alloys," Metallurgical and Materials Transactions A: Physical Metallurgy and Materials Science, vol. 30, no. 10, pp. 2611-2618, 1999.

[12] F. H. Samuel, P. Ouellet, A. M. Samuel, and H. W. Doty, "Effect of $\mathrm{Mg}$ and $\mathrm{Sr}$ additions on the formation of intermetallics in Al$6 \mathrm{Wt} \% \mathrm{Si}-3.5 \mathrm{Wt} . \% \mathrm{Cu}-(0.45)$ to (0.8) Wt.\% Fe 319-type alloys," Metallurgical and Materials Transactions A, vol. 29, no. 12, pp. 2871-2884, 1998.

[13] Q. G. Wang, "Microstructural effects on the tensile and fracture behavior of aluminum casting alloys A356/357," Metallurgical and Materials Transactions A: Physical Metallurgy and Materials Science, vol. 34, no. 12, pp. 2887-2899, 2003.

[14] S. S. Sreeja Kumari, R. M. Pillai, T. P. D. Rajan, and B. C. Pai, "Effects of individual and combined additions of $\mathrm{Be}, \mathrm{Mn}, \mathrm{Ca}$ and $\mathrm{Sr}$ on the solidification behaviour, structure and mechanical properties of Al-7Si-0.3Mg-0.8Fe alloy," Materials Science and Engineering A, vol. 460-461, pp. 561-573, 2007.

[15] E. A. Elsharkawi, E. Samuel, A. M. Samuel, and F. H. Samuel, "Effects of $\mathrm{Mg}, \mathrm{Fe}, \mathrm{Be}$ additions and solution heat treatment on the $\pi$-AlMgFeSi iron intermetallic phase in Al-7Si-Mg alloys," Journal of Materials Science, vol. 45, no. 6, pp. 1528-1539, 2010.

[16] L. Lu and A. K. Dahle, "Iron-rich intermetallic phases and their role in casting defect formation in hypoeutectic Al-Si alloys," Metallurgical and Materials Transactions A: Physical Metallurgy and Materials Science, vol. 36, no. 13, pp. 819-835, 2005.

[17] A. T. Joenoes and J. E. Gruzleski, "Magnesium effects on the microstructure of unmodified and modified Al-Si alloys," Cast Metals, vol. 4, no. 2, pp. 62-71, 1991.

[18] M. A. Moustafa, F. H. Samuel, H. W. Doty, and S. Valtierra, "Effect of $\mathrm{Mg}$ and $\mathrm{Cu}$ additions on the microstructural characteristics and tensile properties of Sr-modified Al-Si eutectic alloys," International Journal of Cast Metals Research, vol. 15, pp. 609-626, 2003.

[19] Y.-H. Tan, S.-L. Lee, and Y.-L. Lin, "Effects of Be and Fe additions on the microstructure and mechanical properties of A357.0 alloys," Metallurgical and Materials Transactions A, vol. 26, no. 5, pp. 1195-1205, 1995.

[20] S. Murali, K. S. Raman, and K. S. S. Murthy, "The formation of $\beta$-FeSiAl5 and BeFe phases in Al7Si0.3Mg alloy containing Be," Materials Science and Engineering A, vol. 190, no. 1-2, pp. 165172, 1995.

[21] S. Murali, K. S. Raman, and K. S. S. Murthy, "Morphological studies on $\beta$-FeSiAl 5 phase in Al-7-Si-0.3Mg alloy with trace additions of $\mathrm{Be}, \mathrm{Mn}, \mathrm{Cr}$, and Co," Materials Characterization, vol. 33, no. 2, pp. 99-112, 1994.

[22] S. Murali, A. Trivedi, K. S. Shamanna, and K. S. S. Murthy, "Effect of iron and combined iron and beryllium additions on the fracture toughness and microstructures of squeezecast Al-7Si-0.3Mg alloy," Journal of Materials Engineering and Performance, vol. 5, no. 4, pp. 462-468, 1996.

[23] L. Zhang, J. Gao, L. N. W. Damoah, and D. G. Robertson, "Removal of iron from aluminum: a review," Mineral Processing and Extractive Metallurgy Review, vol. 33, no. 2, pp. 99-157, 2012.
[24] Conservation of Mass in Chemical Changes Journal-Chemical Society, vol.64, part 2, Chemical Society, London, UK.

[25] F. H. Samuel, P. Ouellet, A. M. Samuel, and H. W. Doty, "Effect of $\mathrm{Mg}$ and $\mathrm{Sr}$ additions on the formation of intermetallics in AI6 Wt Pet Si-3.5 Wt Pet Cu-(0.45) to (0.8) Wt Pet Fe 319-Type Alloys," Metallurgical and Materials Transactions A: Physical Metallurgy and Materials Science, vol. 29, no. 12, pp. 2871-2884, 1998. 

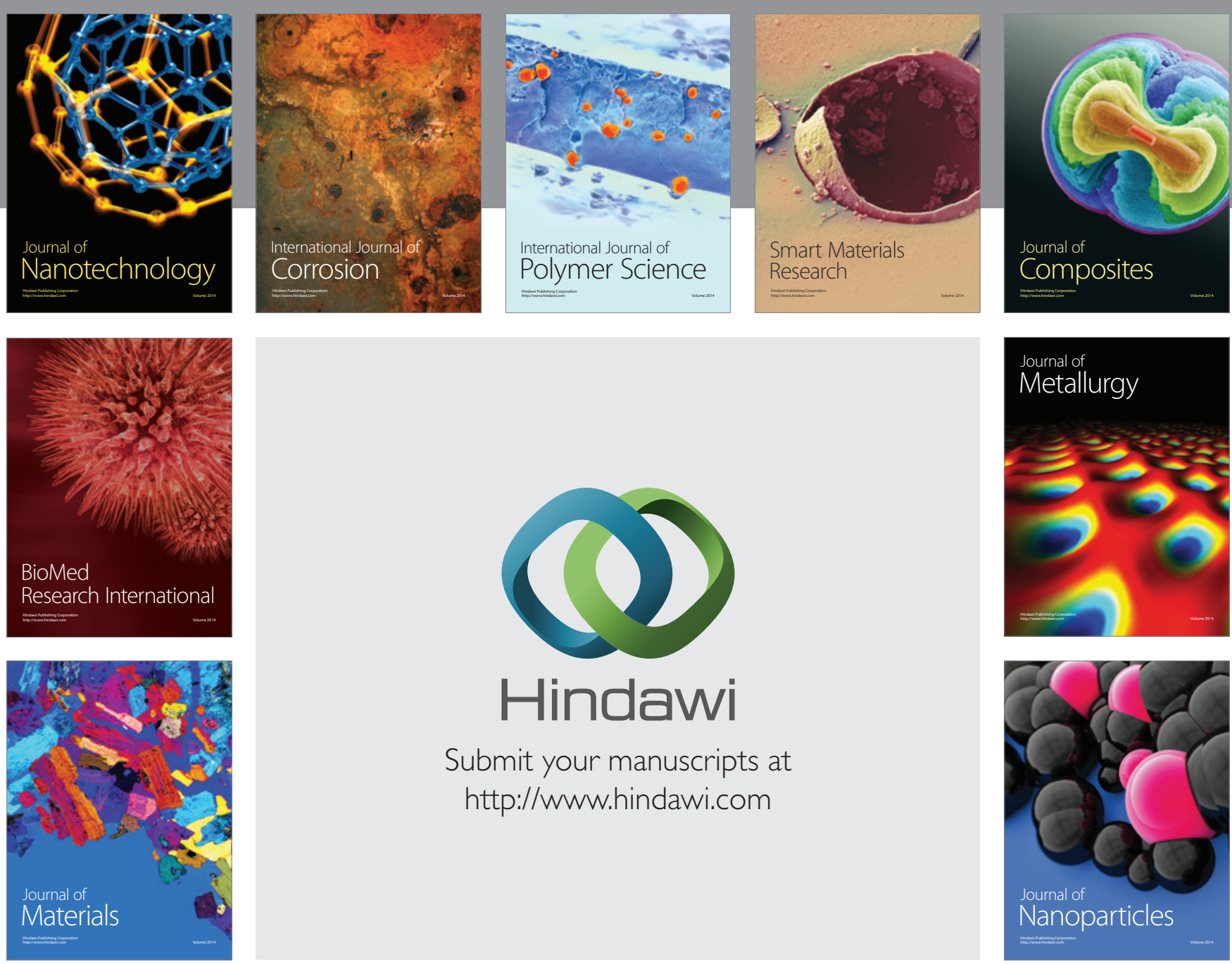

Submit your manuscripts at http://www.hindawi.com
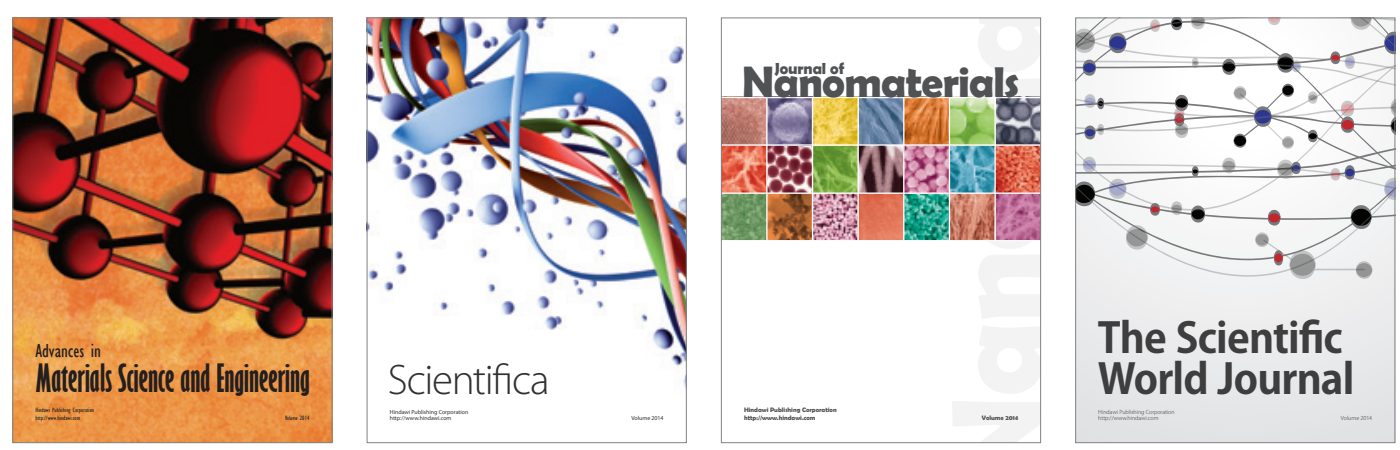

\section{The Scientific World Journal}
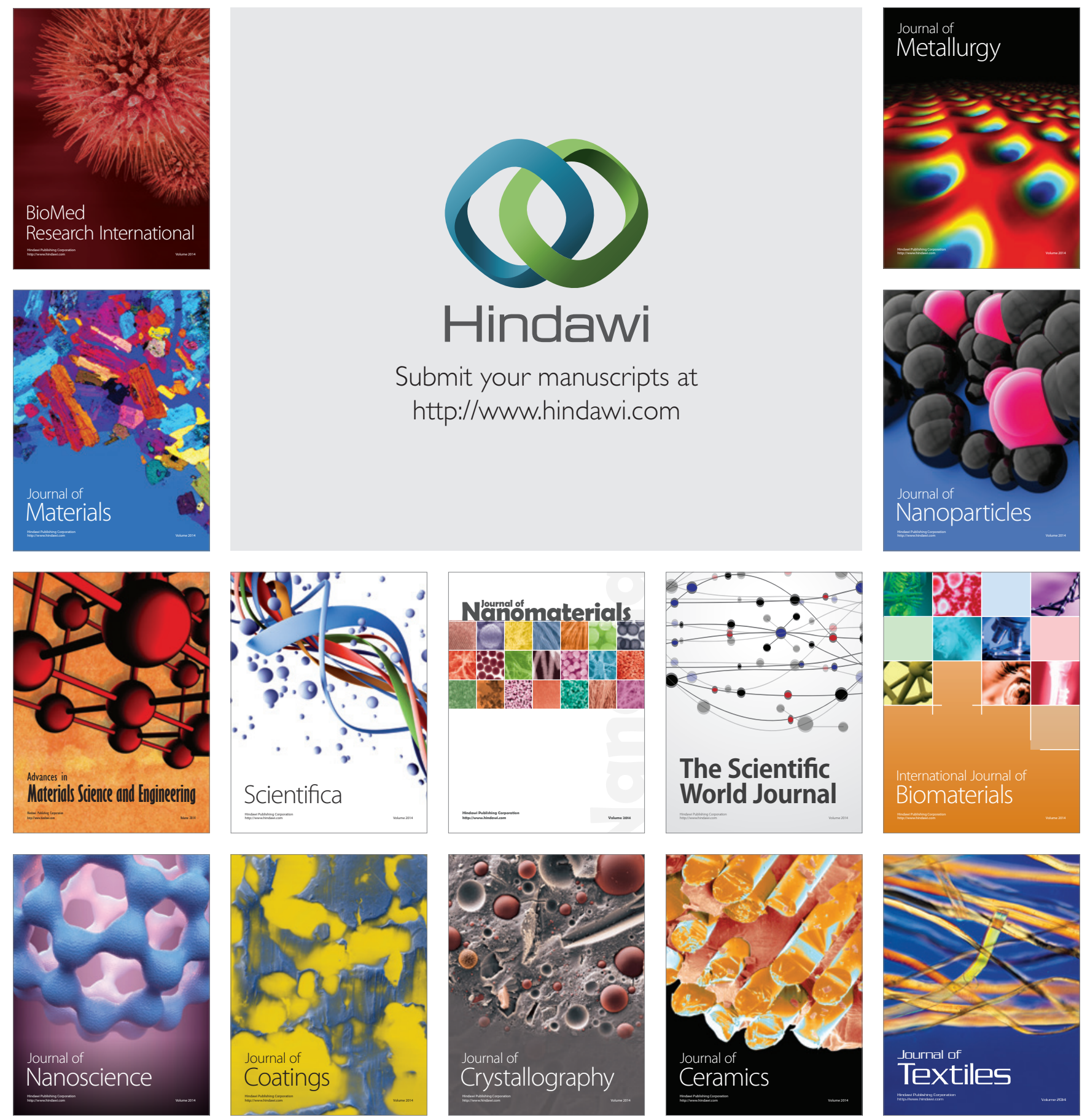